\title{
Universiteit
}

Leiden

The Netherlands

\section{Promoting Human Rights within the Union: The Role of European Private International Law}

Eeckhout, V. van den

\section{Citation}

Eeckhout, V. van den. (2008). Promoting Human Rights within the Union: The Role of European Private International Law. European Law Journal, 14(1), 105-127. Retrieved from https://hdl.handle.net/1887/19063

Version: $\quad$ Not Applicable (or Unknown)

License: $\quad$ Leiden University Non-exclusive license

Downloaded from: $\quad$ https://hdl.handle.net/1887/19063

Note: To cite this publication please use the final published version (if applicable). 


\title{
Promoting Human Rights within the Union: The Role of European Private International Law
}

\author{
Veerle Van Den Eeckhout*
}

\begin{abstract}
This article aims to contribute both to the 'Refgov' project, which is focused on the ambition to find ways of promoting human rights within the $E U$, but also, more in general and apart from the project, to an improved understanding of the crucial place conflict of law rules occupy in the building of a common Europe-a highly political question behind apparently technical issues. In the study the author deals with the parameters, points of interest, etc in relation to private international law which should be heeded if European Member States 'look at' each other's laws, and - in the context of the 'Refgov' project - if the idea is to exchange 'best practices' or harmonise substantive law, or to harmonise private international law, etc further through a type of open method of coordination. The contribution also shows that private international law issues are decisive in respect of every evaluation of the impact of European integration on human rights, both if this integration process takes place through 'negative' harmonisation (for example by falling back on the principle of mutual recognition) and through 'positive' harmonisation.
\end{abstract}

\section{Introduction}

A The Position of PIL: An Exotic Wallflower or a Well-Integrated Participant in Various Companies?

For a long time, the discipline of private international law (PIL) appealed to a limited number of lawyers only. Essentially, this may also still be the case, even though the tide has been turning for some years now.

In recent years, this field has been given a new impetus mainly by Europe, and PIL is now in full swing. On closer inspection, it turns out that the tide is turning in two ways: on the one hand, PIL itself is undergoing an internal metamorphosis, both formally and substantively, but, on the other hand, the relationship between PIL and other fields is changing fundamentally as well. Due to this repositioning of PIL, it is conceivable that PIL issues will appeal to an increasing number of lawyers. In a recent

\footnotetext{
* Prof Dr Veerle Van Den Eeckhout, University of Antwerp, Belgium, and University of Leiden, the Netherlands. This publication has been prepared with the support of the European Commission, Sixth Framework Programme, Reflexive Governance in the Public Interest Project, coordinated by the CPDRUCL. See for more information on this project: http://refgov.cpdr.ucl.ac.be.
} 
contribution, ${ }^{1}$ I described recent developments in PIL, specifically European PIL, as a 'metamorphosis from an exotic wallflower into a well-integrated participant in a variety of companies'. For example, PIL has seen an increasing focus on European integration considerations.

\section{$B$ Point of Departure of the Analysis: The Importance of PIL for a Project which is Focused on the Ambition to find ways of Promoting Human Rights within the Union}

Since PIL now keeps company with specialists in the fields of human rights, nondiscrimination law, European law, comparative law and the like, working together in the project concerning the open method of coordination $(\mathrm{OMC})^{2}$ in the field of human rights, constituted within the 'Reflexive Governance Research Project' (the Refgov project), the question arises as to what the position of PIL in this kind of company should be. Can PIL be ignored in this kind of company and in this kind of project, or should the discipline be integrated into the debates and questions, and could it even play a prominent role in this kind of company? This contribution seeks to answer this very question.

\section{The Limitations and Scope of the Article}

It should be emphasised that this search for an answer will be of only an explorative nature for the time being. This is merely an explorative study. Another limitation of this article lies in the selective nature of the analysis. Aspects that could be quite interesting - for example in relation to ownerships rights, the law of evidence, criminallaw aspects, etc - will not be explicitly included in the analysis for the time being.

Nevertheless, the scope of this contribution may be wider than its title suggests in some areas. For example, the following issues will be addressed: classical PIL questions (questions relating to jurisdiction, applicable law, recognition and enforcement), and the doctrine of the 'internationally mandatory rules' (also known as the 'règles d'application immédiate'); both family law and non-family-law aspects of PIL; both pure PIL issues and PIL issues connected with developments outside the strict PIL domain - such as developments relating to unification and harmonisation of substantive law; migration law developments; PIL issues related to aspects of 'positive' and 'negative' integration.

\footnotetext{
${ }^{1}$ V. Van Den Eeckhout, 'Tien jaar Europees internationaal privaatrecht. Een verrassende metamorfose van exotisch muurbloempje tot goed geïntegreerde deelnemer in diverse gezelschappen' ['Ten Years of European Private International Law. A Surprising Metamorphosis from an Exotic Wallflower into a WellIntegrated Participant in a Variety of Companies'], [2005] Nederlands Tijdschrift voor Europees Recht 289.

${ }^{2}$ OMC can be briefly defined as follows (see, e.g., O. De Schutter and S. Deakin, 'Introduction: Reflexive Governance and the Dilemmas of Social Regulation', in O. De Schutter and S. Deakin (eds), Social Rights and Market Forces. Is the Open Coordination of Employment and Social Policies the Future of Social Europe? (Bruylant, 2005), 1): 'The open method of coordination is one of a number of new governance mechanisms which, from a theoretical point of view, are understood as performing a range of functions. These include fostering mutual learning between the Member States and avoiding or limiting the phenomenon of competitive deregulation in the internal market, while at the same time respecting the diversity of national practices and the existing division of powers between the European Community and the Member States'.
} 
Likewise, the article is not confined to issues explicitly involving human rightsrights currently regarded as such, for example the right of privacy, the freedom of expression, etc. It also deals with discussions that encompass concerns such as the 'protection of the weak party'-for example concerns in relation to employee protection in international labour law.

\section{PIL: Relevant to the Refgov Project in at Least Three Ways}

Let me begin by emphasising, in quite general terms, that the importance of PIL for the Refgov project should not be overestimated, in my opinion. But even if PIL lawyers should be modest about their input in this context, I believe that PIL may certainly be crucially important in some respects and in a variety of manners. For example, PIL could sometimes act as a catalyst in promoting human rights, as an injection mechanism and incentive for triggering a chain reaction, furthering the cause of human rights. In this way, PIL could be a driving force. And a focus on PIL may sometimes cause people to be more alert to potential dynamics that are by no means conducive to promoting human rights, and warn them against counterproductive effects of specific PIL rules as well as against the counterproductive effects of specific rules on PIL rules.

Let me be more concrete now: anyone who tries to define the role of PIL in the Refgov project will soon tend to distinguish three functions, even if, on closer inspection, these functions are closely connected with each other.

A PIL as a Likely 'Target' When Debating the Outcomes of the Use of OMC: A Reason to Anticipate this Outcome and to Include PIL Aspects in the Refgov Project from the Beginning

First and foremost, PIL may be regarded as a rather evident target of the outcome of the Refgov project, in the sense that it is quite conceivable that in due course, during or at the end of the Refgov project, suggestions will be defined in relation to the issue of PIL regulations, PIL directives, the inclusion or clarification of PIL rules in certain areas, or in relation to the manner in which the Court of Justice can best exercise a check on national PIL legislation, or in relation to the approximation of PIL rules by the European Member States themselves.

In other words, one of the Refgov project 'outcomes' will probably be that PIL is to be designated as one of the 'target' disciplines. If this point is recognised, it is valid to argue that it would be fertile and efficient to anticipate this outcome by focusing attention on PIL issues right from the beginning. I will explain this in further detail below.

a) OMC will Sooner or Later Appeal to PIL

i) Point of Departure: About the Functions of OMC

When we try to relate PIL to the Refgov project in this respect, a quotation taken from De Schutter may serve as a point of departure, because the latter discusses the functions of the OMC and argues in this context ${ }^{3}$ that one of its functions could be the following:

\footnotetext{
${ }^{3}$ O. De Schutter, The Implementation of the EU Charter of Human rights through the Open Method of Coordination, Jean Monnet Working Paper 2004 07/04, at 2, available at http://www.jeanmonnetprogram. org/papers/papers04.htlm.
} 
In fields where the competences are shared between the Member States and the Union, the Open Method of Coordination may be seen as a searching mechanism "to identify where an initiative of the Union may be required because of the externalities", both positive and negative, which the action of each Member State produces on all the other States, with which they share a common area of freedom, security and justice, and area in which, in particular, the free movement of persons and the free provision of services are guaranteed and in which competition is to be free and undistorted.

Accordingly, if we keep this observation by De Schutter in the back of our minds, in particular where he refers to 'externalities', it is quite evident that the Refgov project will sooner or later rely on PIL.

\section{ii) Two Reasons why PIL is a likely Target}

As a matter of fact, it is quite straightforward that PIL should be one of the 'targets', and there are two reasons for that.

First, PIL has traditionally been the very discipline 'dealing with externalities in issues of private law'. The existence of 'externalities' is indeed one of the prerequisites to PIL. PIL seeks to regulate the externalities by issuing rules concerning jurisdiction, applicable law, recognition and enforcement. And in regulating 'externalities' in this way, PIL is inevitably confronted with human rights - and, in a broader sense, with concerns relating to the protection of weak parties, etc. In short, PIL provides a way of dealing with externalities, including the confrontation with human rights issues. In this context, it should be underlined, however, that PIL is essentially national law. Admittedly, there are areas where supranational sources are available, and these are sometimes even European sources. But some other areas are still regulated purely at the national level. It is also conceivable that even though supranational PIL rules are available, the latter are not applicable in all EU Member States. 'Problems' could arise either because of the contents of the PIL rules or because PIL rules are sometimes national-level rules, as stated above, which is emphasised to an increasing extent at this juncture: this is said to be the case mainly where PIL rules themselves do not satisfy the requirements occasioned by internal market considerations, or where people within the European area are confronted with problems because countries use different PIL rules, because they do not apply the same legal rules, or because they use different standards when it comes to recognising decisions taken elsewhere, such that people lose rights or are confronted with legal uncertainty if they move to another country; harmonisation could well improve the extent to which rules are predictable and strengthen mutual trust. For this reason, the Refgov project may, sooner or later, address the contents of PIL rules and differences between PIL rules of various countries, which pose 'problems' for citizens. In that event, the Refgov project may address the extent to which it is desirable in an EU context to harmonise the various ways in which the 'externalities' are regulated in a well-defined manner.

At the same time, the foregoing brings us to the second reason why it is to be expected that PIL issues could become a Refgov project target. As a result of the entry into force of the Treaty of Amsterdam, PIL, or at least parts of it, has been 'communitarised'. PIL is linked directly with the idea and the project of the creation of an internal market and an area of freedom, security and justice, the fundamental freedoms and the non-discrimination principle, and under the terms of this movement, farreaching powers have been conferred on the European institutions. This means that European institutions already have the powers to take action in the field of PIL as the occasion arises, including the power to issue PIL regulations. Is it possible to contend 
for this reason that, where De Schutter ${ }^{4}$ discusses the 'legal basis', the legal basis that has already been created for PIL intervention may perhaps come in useful? It should not be forgotten that the Europeanisation of PIL, which manifested itself in the Treaty of Amsterdam, has made the minds 'ready' and prepared to coordinate PIL rules at the European level, and this possibility has already been widely used.

In short, Europe is already interfering with PIL through the process of Europeanisation of PIL, albeit not specifically from the perspective of human rights promotion within Europe, but from the perspective of the promotion of the internal market - as a result of the attempts to encourage legal certainty and to remove obstacles perceived in an internal market - realising the instrumental function PIL may play in achieving an internal market.

This communitarisation phenomenon has triggered sensational developments in the field of PIL, both in terms of procedure and in terms of substance: several European PIL regulations have already been issued and several regulations are in the process of drafting at this very juncture, certainly in areas where European institutions have traditionally exercised restraint, in particular the field of international family law. In addition, the Court of Justice has undauntedly started to intervene in national PIL issues in quite a drastic manner. PIL lawyers are engaged in a debate ${ }^{5}$ on whether-and if so, how precisely-PIL should change as a result of European incentives.

\section{iii) The Current Situation: PIL is in an Interplay of Forces}

At this juncture, PIL is in an area of tension: on the one hand, PIL had already been the subject of instrumentalisation tendencies in the past few years, but, on the other hand, PIL is now increasingly focused on instrumentalisation attempts for European purposes, and all this has resulted in a battle of sometimes contradictory forces. I will explain these forces briefly. ${ }^{6}$

The point of departure in respect of the first force is that PIL had already been 'instrumentalised' in previous years in various ways. Accordingly, the impact of political policy considerations on PIL has manifested itself in recent years such that in various domains there is by no means 'neutral' PIL, still based on the equality of legal systems, but that, on the contrary, PIL rules have been issued in a manner that is conducive to well-defined policy targets. Examples include concerns for the 'protection of the weak party'- see, for example, the rules concerning the applicable law relating to consumer contracts, employment contracts, etc, or concerns about 'supporting' a substantive law result, such as supporting the result of the possibility of marriage (known as 'favor matrimonii' in PIL) or supporting the possibility of divorce (known as 'favor

\footnotetext{
${ }^{4}$ Here and below, quoting De Schutter, I refer to the orginal draft of his contributions to the project (mainly his contribution 'Monitoring Human Rights in the Union as a Learning Process'), as well as to his publication mentioned in n 3 supra.

${ }^{5}$ It should be emphasised, however, that there were already discussions about the relationship between PIL and European law before the Treaty of Amsterdam, both from the perspective of the four freedoms and from the perspective of the non-discrimination principle, and that the Court of Justice, for example, had already intervened in matters such as the cautio judicatum solvi.

${ }^{6}$ In the extensive version of this article (available in its original version at http://refgov.cpdr.ucl.ac.be under 'Publications', 'Fundamental Rights', 'FR4', and to be published in a slightly revised version in Fundamental Rights and the EU-In the Web of Governance (Bruylant, 2007), I have made a first attempt to position - in a fragmentary way - the convergence or tension between 'old' ('classic') and 'new' (European) tendencies to instrumentalise PIL and its interaction with human rights. The extensive version of this article also includes more discussions and footnotes.
} 
divortii in PIL) or supporting the possibility of acquiring maintenance payments. In this context, reference may be made, for example, to developments in international tort law, where there has been an evolution from a focus on the tortfeasor and the place where the wrongful act was committed to more attention for the victim and the place where damage was sustained, certainly partly as a result of political developments, and where there have been pleas for using PIL to make a fitting contribution in the battle against international environmental pollution. ${ }^{7}$ As a matter of fact, the phrase 'making a contribution' was quite recently used in Dutch PIL in the context of the tendency to use PIL for the purpose of combating terrorists. ${ }^{8}$ Where the literature uses the phrase "PIL pollution" in analyses of PIL rules concerning environmental pollution liability, the question arises whether we are really facing PIL pollution in this context. I refer to other tendencies I described myself as 'PIL pollution', especially in relation to Dutch PIL, in various publications in the past, namely using PIL for the purposes of restrictive migration policies and, in a more general sense, for the purpose of restricting public-law rights (rights based on aliens law, social security law and nationality law) of third-country nationals in the Netherlands. ${ }^{10}$

Apparently, the 'importance' of PIL is on the increase, but it seems that people sometimes recognise this importance as a result of their conviction that PIL may be conducive to achieving political targets that are basically associated with other fields. Attempts are then made to 'model' PIL on this basis. In other words, even though the importance of PIL is now recognised, this could, paradoxically, trigger tendencies to absorb, incorporate or, at the very least, model PIL from the perspective of other fields or political objectives in these fields.

No matter how one appreciates - in a positive or negative sense-any specific manner of instrumentalisation within or of PIL, instrumentalisation attempts or tendencies have occasionally led to a kind of 'acquis'. Sometimes these instrumentalisation tendencies are reflected in specific PIL rules issued at the European level, in which case, this concerns a kind of 'acquis communautaire' — see, for example, the rules concerning jurisdiction in contracts of employment, as included in the Brussels Convention, ${ }^{11}$ and the rules concerning applicable law in contracts of employment, as included in the Rome Convention. ${ }^{12}$ In these situations, there could be said to be a kind of acquis communautaire, albeit, with possible variations, at the national level. ${ }^{13}$ Sometimes, PIL

${ }^{7}$ See, e.g., for the Netherlands S. J. Schaafsma, Vervuiling in het conflictenrecht: een onderzoek naar theoretische concepten in praktijk van de internationale milieuvervuiling onrechtmatige daad in het international privaatrechtelijke conflictenrecht [Pollution in Conflict of Laws] (Post Scriptum Reeks, 1994).

8 See P. Vlas, 'Terrorisme en IPR' ['Terrorism and PIL'], [2005] Weekblad voor Privaatrecht, Notariaat en Registratie 663.

9 See Schaafsma, n 7 supra.

${ }^{10}$ In these analyses, I have pointed out several times that the 'instrumentalisation' of PIL for the purpose of encouraging mobility of persons (which Europe is currently trying to achieve in the context of international family law) is much more in line with the essence of PIL and modern PIL, which is essentially, even if only in part, focused on facilitating legal transactions and the target of international harmonisation, certainly now that Europe takes 'favor' tendencies to heart.

11 Brussels Convention on Jurisdiction and the Enforcement of Judgments in Civil and Commercial Matters 27 September 1968, [1990] OJ C189/2 (consolidated version published in 1998 ([1998] OJ C27/1) (the Brussels Convention).

12 Convention on the Law Applicable to Contractual Obligations [1998] OJ C27/34, opened for signature in Rome on 19 June 1980 (the Rome Convention).

${ }^{13}$ On this subject, see also A. A. H. Van Hoek, Internationale mobiliteit van werknemers; een onderzoek naar de interactie tussen arbeidsrecht, EG-recht en IPR aan de hand van de Detacheringsrichtlijn [International 
rules incorporating any manifestation of instrumentalisation for political reasons are not unified - or the supranational sources reflecting these policy considerations are applicable only in specific European Member States. Naturally, even if there is no unification, it is conceivable that each of the European Member States have incorporated political policy considerations into their national PIL to the same or a different extent. For example, several countries have embraced the principle of 'favor divortii'supporting the possibility of divorce - but in different degrees and in a variety of ways. All this may well result in what I could describe as 'modern PIL', although it should be borne in mind that this 'modern PIL' may well vary from country to country, and it may or may not have been given substance at the European level.

It turns out now - and this brings me to the second force I pinpointed above - that recently PIL has become increasingly focused on instrumentalisation tendencies inspired by 'European policy considerations', in particular since the Treaty of Amsterdam. In other words, attempts are being made to use PIL as a tool in achieving European targets. This has resulted in 'pressure' being exerted on 'modern' PIL—of European or national origin - as instrumentalised at an earlier stage.

Occasionally, these 'old' and 'new' PIL incentives match each other well but, at other times, they are in conflict: sometimes the Europeanisation of PIL does not involve any fundamental changes - see, for example, the conversion of the Convention on the Jurisdiction and Enforcement of Judgments in Civil and Commercial Matters (the Brussels Convention) into a Council Regulation to the same effect (the Brussels Regulation), ${ }^{14}$ which did not encroach essentially on the principle of the protection of the weak party, which had been enshrined in the Convention-but sometimes there are fierce debates on the manner in which the existing PIL regime can or cannot be adjusted - examples include the debate on the implications of the country-of-origin principle in the original Proposal for a Directive on Services ${ }^{15}$ for the Rome I proposa $1^{16}$ and the Rome II proposal ${ }^{17}$, the discussion about the impact of the country-of-origin principle in the E-Commerce Directive ${ }^{18}$ and the original version of the Directive on unfair commercial practices, ${ }^{19}$ and the debate on the Proposal Rome II itself.

Mobility of Employees; A Study into the Interaction between Labour Law, EC Law and PIL on the Basis of the Posting Workers Directive] (Sdu Uitgevers, 2000), at 103-104 and M. S. Houwerzijl, De Detacheringsrichtlijn [Directive on Posting of Workers] (Kluwer, 2005), at 4.

${ }^{14}$ Council Regulation (EC) No 44/2001 of 22 December 2000 on jurisdiction and the recognition and enforcement of judgments in civil and commercial matters [2001] OJ L12/1.

15 Proposal for a Directive on services in the internal market COM (2004) 2def/2 (13 January 2004).

16 Proposal for a Regulation of the European Parliament and the Council on the law applicable to contractual obligations ('Rome I') COM (2005) 650 final (15 December 2005).

${ }_{17}$ Proposal for a Regulation of the European Parliament and the Council on the law applicable to noncontractual obligations ('Rome II') COM (2003) 427 (01) (22 July 2003). Amended Proposal for a European Parliament and Council Regulation on the law applicable to non-contractual obligations ('Rome II') COM (2006) 83 final (21 February 2006).

${ }_{18}$ Directive 2000/31/EC of the European Parliament and of the Council of 8 June 2000 on certain legal aspects of information society services, in particular electronic commerce, in the internal market [2000] OJ L178/1 (E-Commerce Directive).

${ }^{19}$ COM (2003) 356 def (namely Art 4, para 1) and COM (2004) 753 def. Directive 2005/29/EC of the European Parliament and of the Council of 11 May 2005 concerning unfair business-to-consumer commercial practices in the internal market and amending Council Directive 84/450/EEC, Directives 97/7 EC, 98/27/EC and 2002/65/EC of the European Parliament and of the Council and Regulation (EC) No 2006/2004 of the European Parliament and of the Council [2005] OJ L149/22 (Directive on Unfair Commercial Practices). 


\section{iv) Ambition: Instrumentalisation of PIL from the Perspective of Human Rights}

\section{Promotion within the Union?}

So what is the relevance of these dynamics and debates for the Refgov project, one may well ask? This may be apparent where we address the question of what position should be taken in this debate by those who are concerned about the 'promotion of human rights'. The following ambition could be defined: how should we evaluate or develop PIL rules in various legal domains that are the most effective tools for the purposes of the instrumentalisation of PIL from the perspective of promoting the protection of human rights within the Union?

In short, if it is true that there are tendencies to instrumentalise PIL for European purposes, and if it is true that there are debates about how to develop PIL in the future, should we then not seize the opportunity to analyse at the same time how PIL is to be instrumentalised such that it is most conducive to the objective of human rights promotion? Or, to put it differently, if there is instrumentalisation of PIL anyway, would it not be a good idea to try and promote a type of instrumentalisation that also fosters human rights at the same time - or, at the very least, that does not impede the promotion of human rights?

Even if the Refgov project conclusion would be that using OMC as a method in the human rights domain is not realistic and fertile, the results of a study as meant above could be useful in the context of the discussion about PIL issues and their relationship with human rights.

Conceivably, OMC could be relevant as a method of promoting human rights in this context in a variety of ways. One hypothesis might be, for example, that OMC could help to create PIL rules (at the European level or Member State level-eventually controlled by the Court of Justice) in a way that encourages the protection of human rights within Europe. Where De Schutter wrote about the function of OMC to define areas of intervention, it is also possible to argue that, where such areas have already been defined, OMC could be used to identify the manner in which action is to be taken - in particular, in areas like PIL. Hence, PIL lawyers might assume the task of heeding the results of the use of the OMC method.

Viewed from this perspective, PIL would be relevant only at the end of the Refgov project. But it might be better to address PIL issues before that: the task would then be to devote systematic attention to PIL issues during the Refgov project, including the manner in which PIL rules (supranational, European or national, and covering jurisdiction, applicable law, recognition and enforcement) regulate 'externalities' at the present moment. For example, the Refgov project might examine the manner in which the various European Member States have dealt with PIL issues, look into what the Member States can learn from each other and how European institutions can learn from the experiences of Member States if they intend to issue PIL rules: what are the 'best practices'? Another possibility is to examine and evaluate the way in which PIL problems are now being solved and whether or not PIL issues are being unified, and the extent to which these are conducive to 'promoting human rights', taking account of the factor of 'feasibility' at the highest level. All this could be carried out with respect to domains such as international family law, international labour law, international tort law, etc, where human rights issues are relevant-or, in a broader sense, wherever concerns such as the 'protection of the weak party', 'family life protection', etc are relevant.

The following provisional conclusion can be drawn in respect of the first role that could be played by PIL in the Refgov project: in this context, it is the impact of human 
rights on PIL and the impact of the Refgov project outcome in terms of its human rights promotion target on PIL, which, for its part, regulates 'externalities', that will perhaps be of particular importance. At this juncture, the crucial decision in this context would be whether the likelihood that the Refgov project will sooner or later affect PIL constitutes a reason for anticipating PIL issues, taking account of current debates, opposition, sensitivity, etc concerning PIL, and, in this way, to think about suggestions relating to what PIL rules could already be 'appropriate' at this stage. In my opinion, this question should be answered in the affirmative.

\section{b) Another Ambition Should be to Examine how Certain Initiatives outside PIL Would Affect PIL}

Because PIL regulates aspects of 'externalities', it is useful to examine the implications for PIL if using OMC yields a suggestion of some kind of coordination or action. This will reveal - still within the context of the first role to be played by PIL in the Refgov project - the extent to which PIL debates could be taken into account in a more indirect manner as well, in particular by focusing attention on the impact of any initiatives and proposals outside PIL on PIL. This concerns the ambition to define and evaluate the manner in which 'solutions' and proposals invented outside the realm of PIL and put forward to foster European integration and, perhaps in part, to promote human rights could, for their part, have an impact on PIL rules, and to evaluate these dynamics.

\section{i) Substantive Law Harmonisation}

This could include interactions between developments relating to the harmonisation of substantive law, on the one hand, and PIL developments, on the other-where PIL is to be taken as including 'internationally mandatory rules'. First and foremost, it is worth mentioning that PIL is sometimes regarded as a way to bridge differences between various legal systems without unifying the latter, in which context PIL is claimed to be a substitute for the harmonisation of substantive law. In addition, it is often claimed that PIL follows naturally from the unification of substantive law, because it is considered necessary to achieve a specified minimum level of substantive law consensus before starting to apply - flexible - PIL rules. Does mutual recognition in this sense also assume a specified degree of harmonisation of substantive law, or does the very concept of mutual recognition allow quite essential differences to continue to exist? In short, the relationship between PIL and substantive law seems to be quite dialectic in nature and may perhaps necessitate a broader analysis. Below, I will pinpoint a number of specific issues that merit further attention.

Implications for issues of 'internationally mandatory rules'. A first point that merits attention in studying the interaction between harmonisation of substantive law and PIL could be the following: what would be the effects of the harmonisation of substantive law on specific PIL domains? This should cover not only the obvious changes in rules in the areas of recognition and enforcement and applicable law but also the implications in respect of 'internationally mandatory rules' - rules that are deemed to be applicable in specific international legal relationships, irrespective of the applicable law that customarily governs this legal relationship. This focus on internationally mandatory rules may raise questions in respect of the following: would the harmonisation of substantive law in some way or other (for example in relation to the type of harmonisation: minimum or complete harmonisation; in relation to the rationale of harmonisation: harmonisation intended to remove internal market obstacles and/or intended to create a minimum protection level for specific persons) have an impact on 
the possibility or the obligation of using well-defined rules as internationally mandatory rules, and, if this is the case, would this be regrettable? In this context, I refer to international labour law studies and to some observations made in a recent Belgian study on non-discrimination law, in particular relating to the impact of the Directive on equal treatment between persons irrespective of racial or ethnic origin, ${ }^{20}$ on the status of national anti-discrimination legislation in an international context, ${ }^{21}$ in particular concerning the possibility of invoking such legislation as internationally mandatory rules within the meaning of Article 7 of the Convention on the Law Applicable to Contractual Obligations. According to Traest, it is possible to argue that once the Directive has come into force in the Member States, national anti-discrimination law cannot be used anymore as internationally mandatory rules. Yet, in his view, antidiscrimination law could still function as a 'loi d'ordre police'. Would it be useful, one wonders, to evaluate from this perspective in what cases it is appropriate to have the possibility of invoking well-defined rules as internationally mandatory rules - and could this evaluation allow us to argue in favour of the unification of substantive law or a specific area thereof? If the conclusion is drawn, for example, that only minimumlevel harmonisation is feasible, and that this would entail the creation of unwanted restrictions when it comes to the possibility of invoking specific rules as internationally mandatory rules, would this lead to the decision that it is better not to opt for harmonisation $?^{22}$

Problems raised in the Ingmar case: the scope of harmonised law and its effects on party autonomy. A second issue that merits attention could be the manner in which the international scope of legislation that includes unified or harmonised substantive law is to be defined. This question has become particularly pregnant in PIL in the light of the Court of Justice's Ingmar decision. ${ }^{23}$ In this case, the Court of Justice faced the legal position of an internationally operating agent. The parties had agreed on the application of the law of a non-European legal system - namely the law of the USA — but the question arose whether European unified rules that provide for specific rights for commercial agents after the termination of their agency agreement could be set aside by this choice of law. These unified rules had been codified in the European Directive on Agency, which is partly ${ }^{24}$ intended to protect the agent, as a 'weak party'. In this case, where the agent performed his activities in the United Kingdom, the principal was established in a non-Member State (namely the USA), and where a clause in the contract stipulated that the contract was governed by the law of that third country, the Court of Justice held that Articles 17 and 18 of the Directive had to be applied, even

${ }^{20}$ Council Directive 2000/43/EC of 29 June 2000 implementing the principle of equal treatment between persons irrespective of racial or ethnic origin [2000] OJ L180/22.

${ }^{21}$ See, e.g., M. Traest, 'Enkele overwegingen over de toepasselijkheid van de wet ter bestrijding van discriminatie in internationale (arbeids)verhoudingen' ['Some Considerations about the Applicability of the Anti-Discriminationl Act in International Labour Relationships'] in D. Cuypers (ed.), Gelijkheid in het arbeidsrecht. Gelijkheid zonder grenzen? [Equality in Labour Law. Equality without Limits?] (Intersentia, 2003), 80.

${ }^{22}$ See also, on the issue of harmonisation, the Communications and the Action Plan on European Contract law, and see also the project European Labour Law Network, available at http://www.elln.eu, an EU-wide network of labour law academics.

${ }^{23}$ ECJ Case C-381/98, Ingmar [2000] ECR I-9305.

${ }^{24}$ See also, on the aim of stimulating a fair competition within the internal market, and the implications of focusing on either this aim (considered by de Boer as the aim of protecting a 'public interest'), or the aim of protecting the agent (considered by de Boer as the aim of protecting an 'individual interest'), Th. M. De Boer, 'Comments with Ingmar', [2005] Nederlandse Jurisprudentie 332. 
though the parties had chosen US law as the applicable law, and the court was of the opinion that these rules could be regarded more or less as internationally mandatory rules. But this Ingmar decision is still quite controversial-for example in terms of its implications for the assessment of the legal position of internationally operating employees - and, in a more general sense, in terms of the question of how the international scope of unified European substantive law is to be defined if the legislation itself is not transparent in this respect. This problem shows how well it is possible to argue that it is necessary to unify substantive law for the purpose of removing internal market obstacles and/or for the purpose of protecting the weak party, but that the question of the international scope of this legislation, and the impact on the parties' choice of law options, ${ }^{25}$ etc, may still arise. This raises the question under what circumstances it is desirable that the parties' possibility of making a choice of law, as in the Ingmar case, should be 'affected'. This means that it is necessary to evaluate whether a specific type of unification of substantive law should be accompanied by the definition of the international scope of these substantive law provisions and, conversely, of the extent to which, even if the unification of PIL rules is achieved, in particular where agreement is reached on the choice of law options, such choice of law may be overridden by the applicability of harmonised substantive law. Because even in the case of the unification of applicable law and in the case of the unification of the choice of law option, it turns out that problems may arise in connection with the relationship with unified substantive law.

\section{ii) Introduction and Proliferation of the Country-of-Origin Principle-}

\section{Mutual Recognition}

When it comes to initiatives outside the field of PIL having an effect on PIL, another issue is undoubtedly the discussion about the implications of the country-of-origin principle on PIL. Naturally, I also refer in this context to the debates on the original proposal of a Directive on Services, debates on the introduction of this principle in the E-Commerce Directive, or in the Directive on Unfair Business Practices, ${ }^{26}$ etc. As De Schutter and Francq ${ }^{27}$ explain in a recent article, the introduction of this 'home country principle' could have (had) serious effects on PIL, and, accordingly, on the protection of internationally mobile employees. Applicable law rules would come under pressure, and the Directive on Posting of Workers ${ }^{28}$ could perhaps be transformed from a model based on minimum protection for cross-border posting of employees towards a model based on maximum protection. In a more general sense, 'regulatory competition' would be stimulated in this way. In PIL, fierce debates are currently being conducted about the significance of the country-of-origin principle; which also turn out to be relevant to the Refgov project, because the proliferation of this principle in private law may have far-reaching effects, for example on the manner in which traditionally weak parties are protected in international situations.

\footnotetext{
${ }^{25}$ As permitted currently, for example, in Art 3 of the Convention on the Law Applicable to Contractual Obligations.

${ }^{26}$ See above for references to these (proposals for) Directives.

${ }^{27}$ O. De Schutter and S. Francq, 'La proposition de directive relative aux services dans le marché intérieur: reconnaissance mutuelle, harmonisation et conflits de lois dans l'Europe élargie' (2005) 5-6 Cahiers de droit européen 603

${ }^{28}$ Directive 96/71/EC of the European Parliament and of the Council of 16 December 1996 concerning the Posting of Workers in the framework of the provision of services [1997] OJ L18/1.
} 
B Introduction/Maintenance of a Specific Type of PIL Rules as one of the 'Conditions of Success' and 'Flanking Measures' of the Refgov Project?

\section{a) Introduction: Some Observations about $O M C$}

Above, it was argued that OMC may possibly help to define better PIL rules or better ways of taking account of PIL rules - and that thinking about and working with OMC should be accompanied by a study of PIL issues. But, as one may suggest, can there not be interaction in the opposite direction as well? Could PIL perhaps somehow support $\mathrm{OMC}$ as well? Is it a good idea to connect the use of OMC with the promotion of specific kinds of PIL rules? Can PIL function as the driving force behind the promotion of human rights?

This idea is inspired by De Schutter where he writes about the 'conditions of success' and 'flanking measures' of OMC. The hypothesis would then be that the inclusion of specific PIL rules may be regarded as one of the conditions of success of OMC.

So this is a second possibility where PIL could be relevant to the Refgov projectand, hence, a second possible role to be played by PIL in the Refgov project. This role may become clearer if one considers the impact of PIL itself on the promotion of human rights, which is connected with the idea that PIL may ultimately help to promote human rights. Earlier, De Schutter referred to the 'conditions of success' and 'flanking measures' of OMC and it is quite possible to conceive that PIL could be one of these conditions of success or 'flanking measures' of OMC, because it is quite certain that where specific conditions have been satisfied, PIL may well be regarded as a catalyst in promoting human rights in Europe; indeed, if certain conditions have been satisfied, PIL may even be regarded as a catalyst in the promotion and flourishing of $\mathrm{OMC}$, ultimately resulting in the promotion of human rights across Europe. Below I will briefly explain a number of potential approaches in this context: how exactly could PIL promote human rights in Europe?

Some of what will be addressed below could also be considered in the light of De Schutter's observations about maximising:

the benefits of regulatory competition between the horizontal units, while limiting the risk of a race to the bottom in the field of human rights ... identify situations where the Union should exercise its powers to protect and promote human rights, while organising the competition between the Union and the Member States through a renewed understanding of the principle of subsidiarity. At both levels, forms of co-ordination between the units concerned (the Member States and the Union) should be invented.

The question arises whether a form of PIL coordination could possibly be this form of coordination. For example, is the organisation of a flexible system of mutual recognition (where it is legitimate to represent 'recognition' as a PIL principle) a form of coordination that can promote human rights? In this context, it is appropriate to refer immediately to the debates about the Directive on Services, which was criticised heavily because the principle of 'mutual recognition' enshrined in it would, in all likelihood, be anything but conducive to the protection of employees - and this criticism was also expressed by the PIL discipline, because PIL achievements (and proposals for the 'Europeanisation' of PIL, above all proposals for a Rome I and a Rome II regulation) could be put aside. On the other hand, it is fitting to point out the potentially 'uplifting' movement that could be the result of an obligation to recognise a same-sex marriage solemnised in a Member State.

The passage below should also be viewed in light of De Schutter's observations about: 
two elements . . lacking in the current system. First, there exists no screening mechanism which would identify, on a systematic basis, where some form of coordination between the Member States - or even some form of legislative action at the federal level-might be required, in order to ensure that, left to themselves, the dynamics of the internal market or of the area of freedom, security and justice, will not lead to a lowering of the level of protection of human rights. Second, there is no mechanism for collective learning between the Member States, despite the usefulness of such a device, if it is properly imagined.

Elsewhere, De Schutter ${ }^{29}$ describes one of the functions of OMC as follows:

... the open method of coordination could be seen as an encouragement to mutual learning, as the solution preferred in certain Member States may inspire the adoption of similar solutions in other Member States, especially where such replication avoids the risk that the implementation of human rights at the level of each State recreate obstacles within the internal market or impede the cooperation between the Member States in the area of freedom, security and justice.

De Schutter and Deakin ${ }^{30}$ define the following hypothesis: 'Thus our hypothesis is that central among the conditions of success of OMC and related processes are mechanisms which function as incentives for the actors to reflect upon the extent to which their understanding of the problem which is to be overcome and their own position may be context-dependent, and therefore may be open to revision in the light of experience ...' and he goes on to say that 'certain institutional frameworks facilitate reflexivity, while others discourage it'. To what extent can PIL be useful? To what extent can PIL be this kind of 'incentive' and to what extent can PIL promote 'reflection', etc? To what extent can PIL act as a catalyst and driving force in promoting human rights, in the knowledge that issues such as 'availability' are often relevant in the context of human rights and PIL has a contribution to make when it comes to issues such as 'availability' and 'transferability'. ${ }^{31}$

\section{b) Attention for PIL Rules which could 'Promote' Human Rights \\ i) PIL Rules may Create Domino Effects}

PIL could act as a driving force in promoting human rights, as suggested above. One possible approach in this context would be a focus on the domino effects that could be created by means of PIL rules, for example when it comes to the effects of the imposition of an obligation on Member States to recognise concepts created elsewhere: this could be perceived as a kind of injection given to a legal system by means of PIL rules, an incentive to develop in a well-defined direction. To substantiate this point, reference can be made to current developments in European international divorce law: as a result of the issue of flexible rules concerning the recognition of international divorces in the 'Brussels II' Regulation, ${ }^{32}$ as well as in the 'Brussels II bis' Regulation, ${ }^{33}$ in which the 'favor divortii principle' has been incorporated, it turns out that European incentives are offered in the direction of a more general tendency to liberalise international divorce law and perhaps even substantive divorce law. There is room for arguments

${ }^{29}$ De Schutter, n 3 supra, at 3.

30 De Schutter and Deakin, n 2 supra, at 3.

31 On this subject, see also infra section II.C.

32 Council Regulation (EC) No 1347/2000 of 29 May 2000 on jurisdiction and the recognition and enforcement of judgments in matrimonial matters and in matters of parental responsibility for children of both spouses [2000] OJ L160/19.

33 Council Regulation (EC) No 2201/2003 of 27 November 2003 concerning jurisdiction and the recognition and enforcement of judgments in matrimonial matters and the matters of parental responsibility, repealing Regulation (EC) No 1347/2000 [2003] OJ L338/1. 
with respect to the necessity to make further progress towards the liberalisation of divorce law once divorces obtained under flexible conditions elsewhere have been recognised. It seems logical to argue that anything that is 'available' elsewhere and that is 'transferable' to the country of origin should also be made 'available' in that country itself - first of all by means of flexible rules concerning jurisdiction and applicable law, and subsequently perhaps for those whose legal relationship manifests itself only in an internal context (because if they are refused access to such 'rights', there would be a situation of reverse discrimination). It is conceivable that these arguments are advanced even if they are not necessarily successful. The awareness and appreciation of these arguments and dynamics may both encourage people to create liberal recognition rules and discourage them from doing so. Principles that are to be taken account of in this context include the principles of non-discrimination, fraud prevention, respect for cultural values in a society, etc. However this may be, divorce law does seem to be undergoing an evolution at the moment, ranging from recognition rules to jurisdiction and applicable law rules, and this may ultimately result - as some people hope and others fear - in an evolution of the substantive divorce law of the Member States whose divorce law is currently not yet as liberal as that of other Member States. In this way, PIL may give rise to a kind of 'backwards progression'. This is precisely what some people are hoping for and that others are fearing, if European divorce recognition rules are introduced or if European recognition rules concerning same-sex marriages were to be introduced - or if the European Court of Justice were to intervene along these lines in national PIL, in particular by forcing a Member State to recognise a same-sex marriage created elsewhere. After all, if a Member State has not introduced the concept of the same-sex marriage in its legal system, it is conceivable that this Member State, perhaps under pressure from the Court of Justice, may recognise a same-sex marriage concluded elsewhere, perhaps even in the hypothetical case that it concerns two of its own citizens. It is conceivable that the Court of Justice could compel this Member State to recognise the same-sex marriage - more or less by analogy with the Grunkin case. ${ }^{34}$

This reference to the Grunkin case brings us to a point that merits attention. In the Opinion in respect of the Grunkin case, reference was made to human rights principles. The question arises whether it is desirable and sufficient to impose European PIL rules only and exclusively where there are purely human rights issues - rights that are currently recognised as such - or can and should European interference extend further, in a process of liberalisation of international family law, in particular in areas where human rights are not discussed as yet. At this juncture, Europe is interfering with international divorce law in a far-reaching manner, but has not yet intervened in issues involving same-sex marriages. If European PIL rules in this field were to be issued, 'injections' and incentives of some sort would be given to the Member States.

\section{ii) Stimulating Reflection on the Differences between Legal Systems: Becoming}

Familiar with Foreign Rules through PIL

A second way of considering PIL as a potential catalyst in promoting human rights can be defined as follows: it is possible to argue, for example, that once Member States are forced under certain circumstances to recognise concepts that have been achieved

${ }^{34}$ Case C-96/04, Grunkin. The Opinion dates from 30 June 2005. The judgment dates from 27 April 2006. The judgment has fizzled out: the Court of Justice stated that 'The Court of Justice of the European Communities has no jurisdiction to answer the question referred by the Amtsgericht Niebüll in its decision of 2 June 2003'. 
elsewhere, this could encourage them in 'collective learning'. ${ }^{35}$ In this way, PIL may well be considered a manner of making the Member States' confrontation with one another's legal systems inevitable. PIL could offer possibilities of becoming familiar with one another's legal systems and use this as a basis for evaluating the best 'solution'.

PIL could then stimulate OMC, in the sense that the confrontation with other legal systems and with 'solutions' in these other legal systems - through the obligation of recognising the achievements of these other legal systems - could contribute towards the promotion of reflecting on a country's own legal system and towards a balanced choice in favour of 'best practices'.

\section{iii) Harmonisation of Internationally Mandatory Rules under Specific Conditions?}

If one reflects on the manner in which the introduction of specific PIL rules could be conducive to achieving the objective of human rights promotion, one should by no means focus only on the 'classical' PIL rules of jurisdiction, applicable law, recognition and enforcement. The significance and potential of internationally mandatory rules, as they exist and are handled in PIL, should be taken into account as well. One question that needs to be addressed is whether OMC should be supported by the introduction or enforcement of internationally mandatory rules, if necessary, in a unified form, as has happened, for example, in the Directive on Posting of Workers. Because this Directive may well be considered a model of European unification of internationally mandatory rules in the domain of international labour law, as far as the cross-border posting of employees is concerned, conceivably, it may be argued that it is necessary to be able to use these rules as minimum standards in every respect-I refer to what was stated above $^{36}$ about the impact of the original proposal for a Directive on Services on this Directive, especially when it comes to the conversion of this Directive from a minimum standard to a maximum standard. Incidentally, the development — or at the very least the enforcement - of specific rules as internationally mandatory rules and the evaluation about whether these are to be used as minimum standards could relate not only to domains such as international labour law, as interwoven with social security rights. This could also be considered, for example, with respect to non-discrimination legislation as such. In this context, I refer to analyses that have already been undertaken into the status of equal treatment legislation in international situations, which have addressed the concrete question of whether these rules may be applicable as rules of normally applicable law in the area of international tort law or international contract law, as 'loi de police' or as internationally mandatory rules. ${ }^{37}$

\section{iv) Using Specific PIL Rules in Defining Certain 'Terms' in Community Legislation}

PIL could act as a driving force in yet another way, namely by giving 'substance' to specific concepts used in European legislation in a well-defined manner. This could concern, for example, family-law concepts such as those used in European migration Directives. For example, the Commission already argued during the preparation of the

${ }^{35}$ PIL lawyers often already try to use differences between the legal systems in a strategic way-eg in the frame of Art 6 of the Rome Convention. See also in this context the information published on the website available at http://europa.eu.int/comm/justice_home/ejn/ (European Justice Network).

${ }^{36}$ See supra section II.A.b).ii).

${ }^{37}$ See, in particular, publications by M. Traest and A. A. van Hoek. See also the Directive on Posting of Workers, $\mathrm{n} 28$ supra, Art 3, para $1(\mathrm{~g})$. 
Directive on the right of citizens of the Union and their family members to move freely within the territory of the Member States that it has no jurisdiction to give further substance to the family-law concepts itself, ${ }^{38}$ but, on the other hand, the Court of Justice does have the power to check specific PIL aspects. By giving well-defined substance to this PIL regulation, it would then be possible to give an injection to the development of family-law concepts in, for example, European migration law. ${ }^{39}$

\section{c) Attention for PIL Rules which could Slow Down and Impede Human Rights Protection and which could Contribute to a Backlash}

Reflecting on the potential role of PIL in the Refgov project in this second sensenamely functioning as a catalyst in promoting human rights and as a hinge-I believe that, if the conclusion is drawn that PIL can indeed act as a catalyst, it can do so only if well-defined PIL rules are used and if specific parameters are satisfied. It is also particularly important to focus attention on any negative effects of the introduction of these kinds of PIL rules.

\section{i) The Risk that PIL Rules may Serve as an 'Excuse' to Stop Further Evolution}

More specifically, it should be recognised that PIL rules may also slow down the promotion of human rights. As such, one should always be alert to any potentially 'perverse' and counterproductive effects of PIL. Issues that merit attention include the extent to which PIL may be used as an 'excuse mechanism', an alibi as it were, where Member States may argue that they definitely - up to a certain point - accept specific principles, but that they cannot be forced to go further than that. For example, would it be legitimate to argue that it is sufficient for a Member State to declare that it is prepared to recognise decisions made or achievements realised elsewhere subject to certain conditions, but that it need not organise this possibility in the Member State itself ? 'Up to that point but not any further', could that be the consequence? In my opinion, one should realise at the very least that arguments of this kind will be advanced, evaluate the chances of such arguments and how regrettable it would be if the 'evolution' would stop at that point: should a situation like that be appreciated as being sufficient, as the best possible result, possibly as the 'second best solution', as in an international context, at least, people who are mobile and/or have a link with a foreign legal system are able to get what they want and may even be able to have this result recognised when they return to their own countries? Then, the final result would be that specific rights are 'available' and possibly even 'transferable' for, at least, a number of people. Or should we always have the ambition to achieve more than that; and if we have this ambition, to what extent should we expect PIL rules to create a domino effect, or to what extent should we fear that PIL rules will slow down further developments? Attempts to find the answer to questions of this kind could help us make our choice of specific kinds of PIL rules as specific rules aimed at promoting human rights. PIL analyses, including analyses of earlier experiences, could be helpful in this respect.

${ }^{38}$ See the Amended Proposal for a Directive of the European Parliament and the Council on the right of citizens of the Union and their family members to move and reside freely within the territory of the Member States (COM (2003) 199 def), at 3.

${ }^{39}$ On this philosophy, see also V. Van Den Eeckhout, 'Communitarisation of International Family Law as seen from a Dutch Perspective: What is New ? A Prospective Analysis', in A. Nuyts and N. Watté (eds), International Civil Litigation in Europe and Relations with Third States (Bruylant, 2005), 509-561. 


\section{ii) Risk of Introducing Principles such as 'Mutual Recognition' by Using the} 'Country-of-Origin Principle' and Present these as PIL Rules

It is quite certain that there are risks in connection with the protection of humans rights in some domains if principles such as the country-of-origin principle are used and are even represented as PIL rules. There is the risk that this principle may change existing PIL rules in a rather drastic manner and involve the obligation of 'mutual recognition' without any further conditions or guarantees - for example the preceding harmonisation and organisation of minimum protection (which, in addition, should not be allowed to function as a model of maximum protection) - in the substantive law of Member States or through harmonisation of internationally mandatory rules, or in the sense of requirements concerning the existence of a 'genuine' link before anything can be recognised, etc. At this point, I once again refer to the discussions about this principle as enshrined in the original proposal for a Directive on Services, the E-commerce Directive, the Rome II-proposal, etc.

\section{Is it Useful to Pay Attention to PIL Issues because PIL can be Considered a Discipline from which Lessons can be Learned in a more General Way?}

PIL analyses could be useful in a broader sense and this brings us to the third potential role to be played by PIL in the Refgov project: PIL may be considered a discipline that has long been confronted with aspects of 'externalities' and human rights, and has thus been able to gain wide experience in addressing several issues that are relevant in discussing the position and development of human rights in Europe. ${ }^{40}$

For my part, I am not convinced that PIL can immediately provide full and adequate answers that are convincing for everybody, but I am of the opinion that it is worth looking into the debates that have been and are still being conducted in PIL circles, the arguments used in these debates, the importance attached to these insights and arguments, etc. In this context, it is certainly worth analysing concepts such as the 'availability' of rights - both in relation to issues of jurisdiction law, applicable law and in relation to recognition and enforcement, as well as the concept of 'transferability'. In this way, one will probably be confronted with arguments and concepts with respect to how to avoid class justice, fraud, 'shopping', etc, which have already been used in PIL debates about such issues as divorce and repudiation. Incidentally, the issue of 'availability' was also raised in the Casus Cha'are shalom ve tsedek v France case ${ }^{41}$ as explained and discussed by Lawson. ${ }^{42}$ This matter could now be considered from the PIL perspective, within the context of the Europeanisation of PIL, in which context, principles such as 'liberal access to justice', 'no-loss-of-rights' and the like seem to be crucial.

\footnotetext{
40 This could be placed in the context of what De Schutter, n 3 supra, at 3-4, describes as a function of OMC: '... the open method of coordination could be an adequate means of better reconciling the requirements of market (economic) freedoms constitutive of the internal market, with human rights, especially social rights, which the Member States are bound to protect and implement under their jurisdiction'. Possibly, PIL could help to find such 'means of better reconciling'!

${ }^{41}$ Cha'are shalom ve tsedek v France, 27 June 2000, European Court of Human Rights.

42 R. Lawson, The Monitoring of Fundamental Rights in the Union as a Contribution to the European Legal Space (III): the Role of the European Court of Human Rights, contribution to the project, available at http://refgov.cpdr.ucl.ac.be and to be published in Fundamental Rights and the EU-In the Web of Governance (Bruylant, 2007).
} 
In a more general sense, the hypothesis would be that it is instructive to analyse debates about 'availability' and 'transferability' in PIL, taking account of arguments advanced and evaluated in 'classical' PIL discussions in the past as well as with arguments that are evaluated at this juncture in the 'new' context of the Europeanisation of PIL.

\section{a) 'Transferability' Issues in PIL Debates}

PIL issues concerning 'transferability' are basically about the possibilities of 'importation', and sometimes also problems in connection with 'exportability'. 'Importability' issues are raised in the context of recognition and enforcement-one of the three classical PIL issues.

Exportability issues are relevant when the question arises whether and if so, in what manner, a Member State should take account of the fact that a legal relationship created in this Member State may not be recognised in another Member State. If Member State A takes account of Member State B's non-recognition of what would be created in Member State A in an anticipatory manner by simply prohibiting the creation of such legal relationship, this kind of anticipation may well act as a brake. Arguments like this were already advanced in Dutch PIL discussions about same-sex marriages, but were put aside at the end of the day.

In this context, it is fascinating to draw attention to the Dutch statutory provision laid down in Section 3(2) of the Marriages (Conflict of Laws) Act (Wet Conflictenrecht Huwelijk), which provides that the solemnisation of a marriage may not be refused on the ground that, under the law of a state of which one of the future spouses possesses the nationality, there is an impediment to such solemnisation that is in breach of Dutch public policy. Accordingly, a foreign impediment to a marriage that is designated as being in breach of public policy in the Netherlands should not be taken heed of in the Netherlands, even if this means that a marriage may be created that will not be recognised in the country where this impediment is in force. It is also fascinating in this context to draw attention to a German court decision ${ }^{43}$ that involved a marriage to be solemnised in Germany between a German divorcee and a Spanish man, where there was an impediment under Spanish law in respect of divorcees, which meant that a marriage solemnised despite this impediment abroad could not be recognised either. The German Constitutional Court involved the fundamental right to marry in its assessment and permitted the parties to marry in Germany, even though it had been argued earlier during the proceedings that the parties had to be protected against the negative effects of a 'limping marriage'.

Any debates on this issue are centred on the possibility of using the non-recognisability in the one Member State of achievements in another Member State as an argument to withhold rights in that other Member State. Debates on this issue are also centred on the question of the extent to which it is relevant in assessing any right whether it concerns a human right as such. Debates on this issue are also centred on the question of how all this is to be evaluated in a European context - a context of stimulating the internal market and the creation of room for freedom, security and justice.

\section{b) 'Availability' Issues in PIL Debates}

'Availability' issues in PIL may be raised in the context of PIL debates concerning jurisdiction, applicable law, recognition and enforcement. If one considers the PIL

\footnotetext{
43 Decision of the German Constitutional Court of 4 May 1971 ([1974] Revue Critique de Droit International Privé 72).
} 
debates in a 'European context', it turns out that these issues are also connected with the difficulty of the separation of 'intra-Community' situations from other situations, as I will explain under c).

First and foremost, as far as the jurisdiction debate is concerned, it is worth remembering that there were times when people were almost systematically 'sent back' to their 'own' national institutions if they wanted any right to be upheld. Arguments based on 'access to justice' may be advanced against such conduct. In this day and age, it often happens that institutions of several countries are competent at the same time. Where litigation in a specific country could yield an advantage in the procedure (for example in terms of the law to be applied), parties are able to make a strategic choice. Placing it in a broader context, potential debates on this issue are centred on the assessment of well-known PIL techniques and 'solutions', such as the forum (non) conveniens, the forum necessitatis, the use of jurisdiction rules such as 'exclusive jurisdiction' rules, attempts to avoid 'class justice', ${ }^{44}$ evaluating the argument that the one court, institution or country may be in a better position to apply a specific law, that this specific court, institution or country may have more knowledge and experience in this field and for this reason people had best be referred to that court, institution or country, etc.

Second, as far as the other procedural PIL question is concerned-the recognition and enforcement question - this is about the possibility of recognising in country A what has been obtained in country B. Should anything obtained in country B be recognised in country A if this right or possibility was not 'available' in country A itself, one wonders? And if country A recognises anything in a situation like that, may this willingness to recognise then be used as an excuse for not recognising this right in the country A itself? In this context, it is worth remembering the experiences of the possibility or impossibility of the conclusion of civil marriages in Lebanon, 'getting' a divorce abroad by the citizens of countries where divorce used to be prohibited at the time, ${ }^{45}$ repudiation in France and other European countries ${ }^{46}$ - and at this juncture, this is relevant in the context of PIL rules concerning same-sex marriages. In these discussions, arguments relating to the significance of 'fraud' are advanced, the assessment of the necessity that the parties have a specific 'link' with a legal system, the possibilities and limitations of 'shopping' for parties whose legal relationship is defined in an international context, the fear of creating a situation that may lead to a 'race to the court by the strongest party', etc.

Finally, as far as applicable law is concerned, it is worth remembering the discussions about the possibilities and limitations in respect of party autonomy that have been held for a long time now. On the issue of choice of law, see also what was stated above ${ }^{47}$ in the context of the Ingmar case - the possibilities parties may have to convert a purely internal legal relationship into an international legal relationship (for example by using

44 This means that there could be class justice if only people who can afford, time-wise or financially, to travel to that other country where a right may be recognised under the applicable law may have effective access to this right.

$45 \mathrm{Cf}$ in this context the case of Johnston and Others $v$ Ireland, 18 December 1986, European Court of Human Rights.

${ }^{46}$ With respect to France, see, e.g., the Simitch case-law: Cass (Fr), 6 February 1985, [1985] Revue Critique de Droit International Privé 369. See on this case-law, e.g., P. Courbe, 'Le divorce international: premier bilan d'application de l'article 310 du Code Civil', [1989-1990] Comité français de droit international privé, Travaux 123; J. Deprez, 'Droit internatoinal privé et conflits de civilisations', (1988) IV Recueil des cours 175 and F. Moneger, 'Vers la fin des répudiations musulmanes par le juge français?', [1992] Journal de Droit International 347.

47 Compare supra section II.A.b).i). 
the choice of law option if this 'internationalisation' of the legal relationship could be advantageous for them). ${ }^{48}$ The conversion from an internal into an international legal relationship could be more attractive, for example, if the parties are able to obtain another-more advantageous - applicable law than the one that normally applies to their internal legal relationship. ${ }^{49}$

\section{c) Scope and Characteristics of Community Law-Delimitation of Intra- Community Cases and the Issue of Reverse Discrimination}

As for the dichotomy between 'internal' and 'international' cases, problems like those relevant in the Ingmar case, allegations concerning reverse discrimination, etc, it is appropriate in this context to refer to the distinction between intra-Community cases and non-intra-Community cases - where the latter may comprise both 'purely national situations' and international situations that are 'extra-Community'. In that case, the discussions about the extent to which differences in approach between intra-Community and non-intra-Community cases are justified are also relevant. ${ }^{50}$ At this juncture, there are developments in this area and pregnant questions need to be addressed. ${ }^{51}$ Below, I will make some observations about the difficulties and complications in respect of the distinction between internal and international cases, and between intra-Community cases and other international family law cases. The latter applies by analogy to some other PIL domains.

In international family law, the Garcia Avello case $^{52}$ reveals that the sociological reality of migration - and, consequently, the sociological reality of the underlying PIL questions - is currently quite diverse. ${ }^{53}$ This means, for example, that descendants from mobile EU citizens, who have never migrated themselves, may still possess the nationality of another EU Member State and may subsequently claim rights from an EU perspective. ${ }^{54}$ As a matter of fact, the personal exercise of the right of free movement within Europe does not need to be confined to the mobility stage but may sometimes result in permanent establishment as well. In addition, the Baldinger case ${ }^{55}$ shows that this is sometimes followed by naturalisation in the country to which the person concerned has migrated, which may involve the transition from an 'internal legal relationship', through a 'European legal relationship' to a 'foreign internal legal relationship'. In this kind of situation, the newly acquired legal position could turn out to be more advantageous or more disadvantageous than that held by the EU citizens in that 'new country' - and than that held by the person himself before the migration. Variations are possible: the originally 'internal legal relationships' may also, after first having become 'European', become 'internal' again, in particular where the person concerned

\footnotetext{
${ }^{48}$ In this context, see, e.g., Art 3(3) of the Rome Convention on the Law Applicable to Contractual Obligations.

49 On this issue, see also my remarks about the problems of international environmental pollution and Art 7 of the Rome II proposal in the full version of this article.

${ }^{50} \mathrm{Cf}$ the discussions raised by the Inspire case of the Court of Justice (C-167/01, [2003] ECR I-10155).

${ }^{51}$ See also Van Den Eeckhout, n 1 supra, especially at 298 and 300-301. I repeat a passage from this contribution.

52 Case C-148-02 Garcia Avello [2003] ECR I-11613.

${ }^{53}$ In this context, see also the Opinion rendered by Advocate General Geelhoed dated 27 February 2003 in the Hacene Akrich case (C-109/01, [2003] ECR I-9607).

54 And see, e.g., in this context also the Chen case (C-200/02, [2004] ECR I-9925), concerning a child with and parents without EU nationality.

55 See the Baldinger decision, C-386/02, [2004] ECR I-8411.
} 
returns to the country of origin-see also the Singh and Hacene Akrich cases. ${ }^{56}$ Confronted with situations of this kind, the European legislator has to address questions relating to the scope of jurisdiction, and relating to the line of action to be adopted if they want to persist in the idea of stimulating free movement: a case that is not yet intra-Community or no longer intra-Community, where it is always possible to draw a distinction between the hypothesis that the case does not have any international elements anyway, or where it does have international elements, which do not make it into an intra-Community case, however. To my mind, decisions that extend beyond the scope of PIL, like the decisions in the Singh and Baldinger cases, ${ }^{57}$ appear to be highly relevant in this context, because it is interesting to study the Court of Justice's considerations in these cases, and subsequently to examine the extent to which the same or other considerations and concerns should play a role in PIL issues. To what extent should there be a focus, for example, in PIL issues relating to the free movement of persons, on the aspect and objective of avoiding limping relationships ${ }^{58}$ - in the light of the fact that limping legal relationships could pose a problem in cases involving mobility, and which could slow down mobility - or also, possibly as an independent issue, the objective of preventing people from losing their rights in the case of mobility - given the fact that the loss of rights in the case of mobility may well discourage people from exercising their right of free movement in actual practice? This may, for example, be related to the consideration in the Baldinger case, where Advocate General Ruiz-Jarabo Colomer took the following ground in his Opinion dated 11 December 2003: ${ }^{.9}$ 'Although citizenship of the Union is not itself capable of conferring the full range of rights which are traditionally attached to membership of a political community, it must at least guarantee that it is possible to change nationality within the European Union without suffering any legal disadvantage'. Placed against the background of current migration law - partly controlled by national institutions, partly at the European level; see, for example, the Directive on Family Reunification ${ }^{60}$ - this could be perceived as being very pregnant indeed. For example, if a legal relationship is first considered to be an 'internal Belgian matter', but is then classified as an 'intra-Community matter' by the exercise of the right of free movement, after which it becomes 'an internal Dutch matter' by naturalisation, could the persons involved lose the 'acquired' family reunification rights they held under Belgian or European law, and could the regime applicable to them change to such an extent that it would be unattractive for them to opt for acquiring Dutch nationality by naturalisation, if it turns out, for example, that the possibilities of having a non-European partner come over will change to a great extent? The question arises as to what extent the European legislator

${ }^{56}$ C-370/90, Singh [1992] ECR I-4265 and C-109/01, Hacene Akrich [2003] ECR I-9607. Another case worth mentioning is C-1/05, Jia [2007] ECR Page I-1.

${ }^{57}$ Also on the basis of the analysis of the Baldinger case, it turns out that, in specific cases, considering specific rights as a 'social advantage' may offer a solution, but that this is not always the case. In this context, see also the Reed case (Case 59/85, [1986] ECR 1283).

${ }^{58}$ Likewise, it was also considered in Garcia Avello, $\mathrm{n} 52$ supra, para 36, that '. . . it is common ground that (such a) discrepancy in surnames is liable to cause serious inconvenience for those concerned at both professional and private levels resulting from, inter alia, difficulties in benefiting, in one Member State of which they are nationals, from the legal effects of diplomas or documents drawn up in the surname recognised in another Member State of which they are also nationals'.

${ }^{59}$ Paragraph 47.

${ }^{60}$ Council Directive 2003/86/EC of 22 September 2003 concerning the Law of Family Reunification, [2003] OJ L251/12. 
will address such issues affecting EU citizens in the future, and how traditional PIL arguments and views in relation, for example, to the concern for international harmony and the preservation of rights in the case of migration should be assessed from a European perspective, from the perspective of human rights promotion. ${ }^{61}$

In the current 'European context', 'classical' arguments and views would then have to be evaluated, taking account of the views, for example, of the Court of Justice in relation to 'fraud' - for example in international company law, the Inspire case, ${ }^{62}$ see also the Hacene Akrich case and the Jia case concerning migration law, including issues about the possibility to maintain the national migration law-accompanied by the European commitment to a 'liberal access to justice', etc.

\section{Conclusion}

\section{A Need for a More Profound and Broader Analysis}

In the extensive version of this article, ${ }^{63} \mathrm{I}$ have tried to explore the relationship between PIL, on the one hand, and European objectives, such as stimulating the international market, protecting the European fundamental freedoms, preserving the principle of non-discrimination based on nationality, and, in addition, the position of human rights, on the other hand. I have made a first attempt to position - in a fragmentary way - the convergence or tension between 'old' ('classic') and 'new' (European) tendencies to instrumentalise PIL and its interaction with human rights.

But the research should go much further. In my opinion, it is sensible to deepen the analysis in the fields mentioned in that first study - both international patrimonial law and international family law - and certainly to involve other fields in the analysis as well. In respect of other fields, too, attempts could be made to position the doctrine and significance of human rights in the area of tensions between European law and PIL. By pursuing this line of action, it could become easier, in my opinion, to establish the position that had best be adopted from the perspective of human rights promotion in current PIL debates, and how, from the perspective of human rights protection, the PIL discipline may attempt to represent PIL either as an obstacle to the internal market or advance it as a tool that could be helpful in the process of European integration and the encouragement of the internal market, what lessons can be learned from PIL, and, in a more general sense, what may be expected from PIL in the context of human rights promotion.

\section{$B \quad$ Should PIL Emerge from its Cocoon and Enter a new Phase?}

And this brings me to my initial definition of the question, in particular the question of PIL as an exotic wallflower or a well-integrated participant in various companies and, more specifically, the position that PIL may have for the purposes of the Refgov project. It seems to be worth the trouble to keep an eye on some of the points mentioned above and give further substance to these.

\footnotetext{
${ }_{61}$ This touches on the interdependencies between European law, PIL, nationality law and aliens law.

62 Inspire, n 50 supra. See also C-212/97, Centros [1999] ECR I-1459 and C-208/00, Uberseering [2002] ECR I-9919.

63 See also n 6 supra.
} 
If one examines such questions concerning PIL, human rights and European law, one finds oneself, as it were, 'at the crossroads' of various disciplines interacting with each other; in this context, attention should be paid both to 'classical' studies and to up-to-date studies concerning recent developments and dynamics, and the manner in which these interact with each other. Both studies into the interaction between human rights and European law - for recent publications on this issue, see the studies addressing the problems of the Omega case - and studies into the interaction between PIL and human rights (old discussions, for example those relevant in the above decision by the German Constitutional Court of 4 May 1971), and into the interaction between PIL and European law ('classical' and 'new' debates, before and after the Europeanisation of PIL) would ultimately have to be combined in an analysis of the interaction between PIL, European law and human rights. This type of analysis had been partly carried out even before the Europeanisation of PIL. For example, this could relate to analyses about the principle of non-discrimination based on nationality in the confrontation with the cautio judicatum solvi, or about the principle of 'fair trial' as a ground for refusal for recognition in the Brussels Convention. ${ }^{64}$ At this juncture, after the Europeanisation of PIL, debates are being conducted about questions raised in the context of the Garcia-Avello ${ }^{65}$ and Grunkin cases, ${ }^{66}$ the legislation to be drafted in the field of international tort law, the impact of the country-of-origin principle, the concept of a 'community public order', etc.

All in all, from the perspective of the Refgov project, which is focused on the ambition to find ways of promoting human rights, the following crucial questions emerge: what role may PIL be expected to play if human rights are to be promoted? What position would lawyers wanting to promote human rights have to take in PIL issues, and how should they take account of PIL issues? And what lessons can lawyers 'learn' from PIL as a discipline or the debates in PIL that may still be conducted?

If one tries to answer such questions, one defies PIL, as it were, to emerge from the safe, snug cocoon in which the discipline has wrapped itself until now. PIL will then have the opportunity to develop into a full-fledged and worthy participant in the Refgov project and, more in general, to develop into a worthy participant in companies of specialists of human rights, non-discrimination law, European law and comparative law.

First Submitted: June 2006

Final Revision Accepted: April 2007

\footnotetext{
${ }^{64}$ In this context, see, e.g., ECJ 28 March 2000, Case C-7/98 Krombach, and studies thereon.

${ }^{65}$ C-148/02, Judgment dated 2 October 2003.

${ }^{66}$ C-96/04. The Opinion dates from 30 June 2005. Judgment dated 27 April 2006.
} 